\title{
IS APARTHEID OOK OP EKONOMIESE GRONDE GEREGVERDIG?
}

Die mening word vandag dikwels uitgespreek (ook deur Nasionaliste) dat apartheid nie op ekonomiese gronde geregverdig kan word nie; of anders gestel, dat apartheid van die blankes te groot offers sal verg; of nog sterker gestel, dat die blankes op ekonomiese gebied nie sonder die naturel sal kan klaarkom nie.

Persoonlik voel ek dat teen bogenoemde opvatting standpunt ingeneem moet word. Ek stel dit dan ook dat algehele segregasie (m.a.w. ook ekonomiese segregasie) tussen blankes en naturelle in Suid-Afrika ook op ekonomiese gebied geregverdig is en uiteindelik tot voordeel van albei groepe van die gemeenskap sal wees. M.i. moet die lae produktiwiteit van die blanke en die nie-blanke werker in die algemeen, in 'n belangrike mate aan die integrasie van nie-blanke werkers in die blanke 
ekonomie toegeskryf word. In dié verband wil ek graag wys op die volgende aspekte van die saak.

Ten eerste is daar die tradisionele opvatting van „kafferwerk" wat die produktiwiteit van die blanke baie nadelig beïnvloed. Sekere soorte werk word in die reël nie alleen as nederiger of minder aangenaam beskou nie, maar as werk wat slegs deur die naturel gedoen moet word. Die blanke is in dié verband veral oordrewe fyngevoelig oor sy waardigheid. Die toestand het vandag reeds so ver gevorder dat nie 'n bepaalde soort werk nie, nie die loon wat aan die werk verbonde is nie, maar die vraag of vir so 'n bepaalde soort werk feitlik nog net naturelle gebruik is of nie, beslis of dit vir die blanke vernederend is al dan nie. Sekere soorte werk, waarvoor die naturel oorspronklik nie die nodige aanleg gehad het nie, word mettertyd „kafferwerk", sodra dit oorwegend deur hulle gedoen word. As blanke werkers nou deur omstandighede gedwing word om die soort werk te verrig, is die lusteloosheid en lae produktiwiteit seker vir elkeen opvallend. Hierdie verskynsel het al so verbreid geraak dat die blanke ouers nie meer hulle kinders so ver kan kry om eenvoudige huiswerk of tuinwerk te verrig nie-die ouer sowel as die kind beskou mos sulke werk as "kafferwerk". Wat is die gevolg? Die kinders boer op straat of vorm bendes, wat noodwendig moet lei tot jeugmisdaad en ander sosiale euwels. Die vreugde wat die arbeid bied, word nie meer erken nie.

Vandag vind ons nog 'n ander uitvlocisel van die 1radisionele opvatting van „kafferwerk" hierin, dat werkers nie hulle beste sal lewer as daar vir 'n „baas" gewerk moet word nie. Die blanke werker is dikwels die mening toegedaan dat hy nou in dieselfde verhouding teenoor die baas staan as wat die naturel voorheen teenoor hom gestaan het. Dit skyn asof die leuse van die werker in alle vertakkinge van die lewe vandag is: maksimum- en steeds hoër lone vir minder en steeds minder werk, en met minder dissipline.

Indien Suid-Afrika sy ekonomiese posisie wil handhaaf in 'n wêreld wat al hoe meer op 'n skerp mededingende grondslag berus, sal die tradisionele opvatting teenoor harder en gereelder werk 'n radikale verandering moet ondergaan. Elke persoon moet besef dat hy teenoor God verantwoording verskuldig is van hoe hy sy opgelegde taak verrig. Maar omdat hy ook lid is van ' $n$ volk, is die arbeid (van die man, die vrou en die kind) nie slegs 'n persoonlike saak nie. Daar moet weer opnuut besef word dat die straatveër, wat volgens sy aanleg sy taak met nougesetheid en eerlik- 
heid verrig, van meer waarde vir die volk is as die professor, lektor en student wat sy werk verwaarloos.

M.i. sal die aanwakkering van nasie- en roepingsbewustheid en die wil by die ouers sowel as by die kind om te werk (dus ook om enige werk te verrig), die beste kan geskied deur'n beleid van algehele segregasie toe te pas. Algehele segregasie sal die opvatting van „kafferwerk” by die blanke baie gou laat verdwyn. Ook die naturel sal gou leer dat hy sy nasietrots alleen sal kan behou as hy in sy eie gebied en onder sy eie mense toegelaat word om, ooreenkomstig sy aanleg, vanaf die laagste tot die hoogsgeskoolde werk te verrig. Wat nog belangriker is, is dat die naturel baic gou tot die besef sal kom dat sy lae lewenstandaard nie net toegeskryf kan word aan die sogenaamde onderdrukking deur die blanke nie, maar dat dit in 'n baie groot mate afhang van die lae produktiwiteit van die arbeid. Alleen onder 'n stelsel van algehele segregasie sal gesonde mededinging moontlik wees en sal loonstelsels wat op produktiwiteit berus, toegepas kan word. Die sogenaamde "goedkoop" naturellearbeid is nie so goedkoop as wat meesal aangeneem word nie. Om maar een voorbeeld te noenı: die "goedkoop" naturellearbeid het te dikwels nog meganisasie op baie gebiede van die ekonomiese lewe in Suid-Afrika vertraag.

'n Tweede faktor wat in ons rasse-geïntegreerde ekonomie ongetwyfeld 'n nadelige invloed uitoefen, is die cienaardige loonstruktuur wat eie aan Suid-Afrika is. Die loonstruktuur van Suid-Afrika word eienaardig genoen, omdat die loonskale van geskoolde arbeiders te hoog is, sowel in verhouding tot die skale van ongeskoolde arbeidskragte as in verhouding tot die gemiddelde arbeidsproduktiwiteit. Terwyl die verskil tussen die hoogste en die laagste loonskale in die Westerse wêreld gewoonlik ongeveer $30 \%$ en selde hoër as $50 \%$ is, bedra dit in die Unie 'n paar honderd persent.

Die rede vir die voortbestaan van die eienaardige loonstruktuur in Suid-Afrika kan hoofsaaklik toegeskryf word aan die toepassing van die kleurslagboom in al sy verskillende vorme - wetlik administratief en konvensioneel - en aan die mag van die blanke vakbondwese. Op grond van die kleurslagboom vind ons dat die blanke, selfs wanneer hy presies dieselfde werk doen as die nie-blanke, 'n hoër loon as die nieblanke ontvang. In die geval van die staat of ander openbare liggame en privaatonderneminge is daar gewoonlik 'n dubbele loontarief, een vir blankes en een vir nie-blankes, of anders word bepaalde mindergeskoolde werk vir die blankes gereserveer. Dit beteken dat werkers nie op grond 
van hul relatiewe produktiwiteit in diens geneem word nie en dat die ekonomiese magte wat gewoonlik aan die werk is om gelyke lone vir gelyke produktiwiteit te bewerkstellig, nie hul invloed kan laat geld nie.

Voor-uniale wetgewing was veral gemoeid met die uitbreiding van die naturelle- en gekleurde arbeid, i.p.v. die beperking daarvan. Dit was veral in die noordelike provinsies die geval waar die Paswette (Wet 22/ 1895, 23/1899 en Ord. 17 van 1903) gepasseer is op aandrang van die mynowerhede. Die doelstelling van die paswette was veral om die wegdros van naturellemynwerkers teen te gaan. Hierdeur is natuurlik ook indirek invloed op die lone van die naturelle uitgeoefen.

$\mathrm{Na}$ die totstandkoming van die Unie vind ons egter die neiging in industriële wetgewing om die kleurslagboom sterker te beklemtoon en is daar al meer teen die naturelle gediskrimineer. Die beginsel om sekere werk vir die blanke te reserveer is reeds deur die Transvaalse Administrasie na die Anglo-Boereoorlog erken en in die "Labour Importation Ordinance" van 1904 geïnkorporeer. In skedule I van die Ordonnansie is duidelik bepaal in watter beroepe Chinese nie opgeneem mag word nie. Volgens die Mijnen en Bedrijwenwet van 1911 is die beginsel aanvaar waardeur gekleurdes uitgesluit is uit sekere verantwoordelike posisies op die myne in die Transvaal en Oranje-Vrystaat. Nadat dié regulasies in 1923 ultra vires verklaar is, is die wet in 1926 so gewysig dat dit slegs naturelle belet om sekere posisies te beklee.

Buite die mynbedryf is daar geen wetlike kleurskeidslyn nie, maar dit verhinder nog nie dat loonwetgewing in dié lig beskou en toegepas kan word nie. Die wet wat veral aangeval word is die Vakleerlingwet van 1922 en soos later gewysig. Daar word wel geen melding in die wet gemaak van diskriminasie op grond van kleur nie, maar in die praktyk is die wet wel 'n struikelblok wat gekleurdes betref en word naturelle belet om as vakmanne opgelei te word. Blanke werkgewers gee immers voorkeur aan die inskrywing van blankes as vakleerlinge.

In die Unie word die vraagstuk van die loonbepaling van alle werkers hoofsaaklik beheer deur die Nywerheidsversoeningswet en die Loonwet. Die Nywerheidsversoeningswet maak voorsiening vir die registrasie en reèling van blanke vakverenigings en werkgewersorganisasies, vir die voorkoming en beslegting van geskille tussen werkgewers en werknemers en vir die reëling van diensvoorwaardes deur ooreenkoms en arbitrasie. Hierdie vakbonde het met verloop van tyd heelwat druk uitgeoefen op die werkgewers en aansienlike loonsverhogings verkry-dikwels ten koste van 
die ongeorganiseerde groepe. Die Loonwet funksioneer d.m.v. die Loonraad en die Raad kan weer aanbevelings maak insake minimum lone, afnemende skale van beloning vir jongelinge en ongekwalifiseerde volwassenes in verhouding tot die gekwalifiseerde aantal en in die algemeen enige saak rakende indiensneming. Die wet verleen egter geen reg aan die Raad om te diskrimineer op grond van ras of kleur nie. Die Raad kan aanbevelings maak t.o.v. alle aspekte van die skale waaronder betaling moet geskied. Alvorens enige aanbeveling gedoen word, is die Raad deur die bepalings van Artikel 8 gebind om onder andere die volgende te oorweeg:

(i) die bekwaamheid van werkgewers in die betrokke beroep of beroepsafdeling om hulle onderneming met sukses voort te sit indien enige aanbevelings tot uitvoering gebring word, met inagneming van die afstand van markte, vervoerkoste en enige omstandighede wat ter sake is;

(ii) die lewenskoste in enige streek waarin die betrokke beroep of beroepsafdeling beoefen word;

(iii) verder moet ook in ag geneem word die beleid van "beskaafde" arbeid, d.w.s. ten einde te verseker dat hoofsaaklik blankes uit die aktiewe industriële beleid van die regering voordeel trek, en beskerming slegs verleen word op voorwaarde dat 'n bevredigende verhouding tussen ,beskaafde" en "onbeskaafde" werkers in elke nywerheid in stand gehou word. Eintlik is die beleid van die ,beskaafde" arbeid so opgestel dat dit nie 'n kleurslagboom insluit nie. So is dit van toepassing gemaak op alle persone wie se loonstandaard ooreenkom met dié standaard wat gewoonlik volgens die standpunt van die blanke as draaglik beskou word. In die praktyk staan slegs die kleurlinge op gelyke voet met die blankes. Die uitwerking van die beleid van „,beskaafde” arbeid in die nywerhede en openbare werke is dus baic dieselfde as die kleurslagboom wat op die myne toegepas word. Die groot beswaar teen die toepassing van die beginsel van „beskaafde" arbeid is dat diegene wat dus 'n lae lewenstandaard het, 'n lae loon moet kry, en 'n lae loon beteken weer 'n lae lewenstandaard, en sodoende word die toestand verewig.

Persoonlik voel ek dat die hoogs kunsmatige loonstruktuur in SuidAfrika ongetwyfeld veel daartoe bygedra het om die onekonomiese aanwending van ons arbeidskragte (blank sowel as nie-blank) te bestendig. Dit ontneen aan die nie-blanke werker die normale aansporing om sy posisie te verbeter, terwyl die blanke werker ook nie sy beste sal lewer indien hy met die nie-blanke sal moet meeding nie. .

Die oplossing van die bogenoemde probleme lê m.i. nie in ekonomiese 
integrasie, soos sommige persone beweer nie, maar in algehele ekonomiese segregasie aangesien dit die enigste praktiese en blywende oplossing kan wees. Nywerhede moet gedesentraliseer word en sommige nywerhede moet in naturellegebiede opgerig word. In hierdie naturellegebiede kan die naturel aangemoedig word om die gawes en aanleg waaroor hy mag beskik, te ontwikkel en tot die grootste voordeel aan te wend. Ek hoor natuurlik al klaar die argument dat ons nou reeds 'n geweldige tekort aan arbeidskragte het en dan word nog aanbeveel dat die naturelle na hul eie gebiede moet teruggaan. Daar moet egter onthou word dat daar baie immigrante is wat gewillig is om na Suid-Afrika te kom mits ons gewillig is om geskoolde sowel as ongeskoolde werkers te aanvaar. Die vermenging van verskillende rasse op werks- en woongebied het nog altyd tot wrywing gelei in alle dele van die wêreld. Wrywing sal weer lei tot verkwisting van energie en andersins tot laè produktiwiteit. Namate segregasie verder deurgevoer word, sal die eienaardige loonstruktuur en die opvatting van „kafferwerk” verdwyn. In die plek daarvan kan aansporingslone kom waar die werker in ooreenstemming met sy produktiwiteit beloon word. Dit sal ongetwyfeld 'n gesonder gees van mededinging aanwakker wanneer blanke teenoor blanke en naturel teenoor naturel te staan sal kom. Die naturel en sy raadgewers sal dan nie meer kan aanvoer dat die blanke se hoër loon slegs aan die toepassing van die kleurslagboom toegeskryf kan word nie. Die naturel sowel as die blanke sal gou besef dat daar harder gewerk sal moet word indien 'n hoër lewenstandaard gehandhaaf wil word. Die blankes sal dan weer leer om enige tipe werk te verrig ondat die opvatting oor ,kafferwerk" met algehele segregasie baie gou sal verdwyn.

B. VAN DEVENTER.

Desember 1955. 